\title{
PRZYGODA I WYGNANIE. DWIE PERSPEKTYWY DOŚWIADCZANIA MIGRACJI W MIEŚCIE, JEDNO WYZWANIE POLITYKI MIEJSKIEJ
}

\begin{abstract}
Kubera Jacek, Przygoda i Wygnanie. Dwie perspektywy doświadczania migracji w mieście, jedno wyzwanie polityki miejskiej [Adventure and Exile. Two kinds of migration experience, one challenge of urban policy] edited by J. Kubera, Ł. Skoczylas - „Człowiek i Społeczeństwo", vol. XXXVII, Poznań 2014, pp. 91-102, Adam Mickiewicz University Press. ISBN 978-83-232-2764-9. ISSN 0239-3271.

The paper presents two sociological approaches to the migration experience. In the first approach, which corresponds to Georg Simmel's essay The Philosophy of adventure, migration is regarded as an adventure. In the second approach, which was particularly explored by Abdelmalek Sayad (La double absence), migration is experienced as an exile. However, "adventure" and "exile" describe two different model situations of the migrant's experience; they both cause the presence of homesickness and the lack of feeling that the inhabited space is a new home. This is why the migrant's experience of adventure or of exile is treated in the paper as a challenge for every city policy. In the context of contemporary theories (like the metamodernism of Vermeulen and van den Akker), the author of the paper presents the propositions of urban policy which could meet the migrants' needs and make them real members of the urban community.
\end{abstract}

Jacek Kubera, Uniwersytet im. Adama Mickiewicza w Poznaniu, Instytut Socjologii, ul. Szamarzewskiego 89c, 60-568 Poznań, Poland. Autor jest stypendystą Fundacji Uniwersytetu im. Adama Mickiewicza w Poznaniu na rok 2013/2014.

\section{PRZESTRZEŃ JAKO WARTOŚĆ SPOŁECZNA}

W niniejszym opracowaniu zostaną omówione dwie różne perspektywy doświadczania własnej migracji, a następnie współczesne, pojawiające się po postmodernizmie, propozycje takiej polityki miejskiej, która potrafiłaby przezwyciężać przeżywanie przez imigrantów Przygody lub Wygnania, sprawiając, że w nowej, odkrywanej przestrzeni czuliby się oni jak u siebie, czyli jak w przestrzeni własnej. Jak bowiem pisał Florian Znaniecki (1938: 91), klasyk socjologii miasta i jednocześnie socjologii migracji, cechą każdej przestrzeni jest to, że jest zawsze czyjaś - przede wszystkim w znaczeniu społecznym, niekoniecznie zaś prawnym czy ekonomicznym: 
„[...] zespoły ludzkie, zwłaszcza zespoły tworzące grupy zorganizowane, zwykle mają w sferze swego zbiorowego doświadczenia i działania pewne wartości przestrzenne, które traktują jako swą wspólną «własność» nie w sensie czysto ekonomicznym, lecz w ogólniejszym znaczeniu, że nimi wspólnie «władają», posługując się nimi dla wykonywania pewnych czynności zbiorowych lub upoważniając jednostki do posługiwania się nimi przy wykonywaniu pewnych czynności indywidualnych".

Dodajmy, że określonej przestrzeni, czyli „wartości przestrzennej” w ujęciu F. Znanieckiego, nie sposób rozpatrywać w oderwaniu od ogółu wartości współdzielonych i doświadczanych przez daną zbiorowość (społeczno-terytorialną, ale także np. religijną, klasową, narodową, zawodową, zbiorowość osób o podobnych upodobaniach estetycznych czy wykonujących pewien zawód itd.). Każda przestrzeń, jak pisze ten autor (1938: 91), jest zatem "składnikiem jakiegoś nieprzestrzennego systemu wartości, w odniesieniu do którego posiada swoistą treść i znaczenie". Co ważne z punktu widzenia migrantów, zmieniających swe położenie przestrzenne i społeczne, o uczestnictwie jakiegoś człowieka w danej przestrzeni decyduje nie on sam, ale władająca nią zbiorowość:

\footnotetext{
„Sprawa jest podobna jak z innymi wartościami zespołowymi. [...] Człowiek, któremu zespół nie przyznaje prawa do obecności w swej wartości przestrzennej, podobnie jak człowiek, któremu zespół nie przyznaje prawa do udziału w swym kapitale, w swej religii, w swych przywilejach, nie jest dopuszczony do uczestnictwa, jeśli zaś samowolnie zaczął uczestniczyć, zostaje usunięty, może nawet być potraktowany jako przestępca profanujący wartości zbiorowe" (Znaniecki 1938: 94).
}

Podobnie o przestrzeni miejskiej wypowiadali się Aleksander Wallis (1977, zwł. s. 79-139), Georg Simmel (2008 [1903]: 365-385) i inni przedstawiciele humanistycznej, kulturalistycznej szkoły socjologii miasta. Łączyło ich przeświadczenie, że przestrzeń miejska jest dziełem ludzkim i trudno ją zrozumieć, abstrahując od nadawanych jej przez ludzi sensów i znaczeń. Wszyscy zgodziliby się ze Znanieckim (1938: 94), kiedy stwierdza, że „Przyznawane człowiekowi prawo obecności w pewnej przestrzeni wchodzi [...] w skład jego stanu socjalnego". Warto zatem zastanowić się, jaki jest, używając dzisiejszych terminów, status społeczny migranta.

\section{MIGRANT JAKO CZLOWIEK „POMIĘDZY"}

W tym kontekście rację miał Pierre Bourdieu (1999: 12), kiedy stwierdzał, że dla zewnętrznych obserwatorów problematyczność w definiowaniu migrantów wynika stąd, iż są atopos - podobnie jak Sokrates zdaniem Platona, 
co wskazywałoby na pewną ponadhistoryczną wagę zagadnienia. Migranci są atopos, czyli ludźmi znikąd, którzy są jeszcze w trakcie przenoszenia się z jednego miejsca na drugie, a przez to są ludźmi, o których trudno powiedzieć, czy i w jakim wymiarze mają prawo traktować daną przestrzeń jako własną. "Ani obywatel, ani cudzoziemiec, ani tak naprawdę po naszej stronie, ani zupełnie po obcej stronie, imigrant znajduje się w miejscu «mieszańców», o którym także mówi Platon, na granicy społecznego istnienia i niebytu" - tak charakteryzuje migranta Bourdieu (1999: 12). Warto przy tym powiedzieć, że emigracja i imigracja to $\mathrm{w}$ istocie dwie strony tego samego procesu (Sayad 1999: 56-58), który - użyjmy metafory przesadzanego drzewa - określić można jako zakorzenianie się $\mathrm{w}$ jednym miejscu przy jednoczesnym, stopniowym lub gwałtownym, odcinaniu korzeni w drugim, w tym, w którym kiedyś się wyrosło. Przez długi czas „ludzie w ruchu” znajdują się równocześnie $\mathrm{w}$ dwóch miejscach, w dwóch strukturach społecznych, często między dwiema kulturami. Proces migracji, czyli przemieszczania się - zarówno w sensie przestrzennym, jak i społecznym wieńczą zazwyczaj dopiero narodziny „na nowym” dzieci migrantów, które mówiąc "jestem stąd", mogą myśleć przede wszystkim o jednej zbiorowości i jej przestrzeni, jeśli tylko nastąpiła pomyślna integracja ich rodziny ze społecznością przyjmującą.

Decyzja o tym, kiedy kończy się dla migranta jego podróż z jednego społecznego i przestrzennego jednocześnie - miejsca na drugie, ostatecznie dokonuje się w świadomości migrującego. Przyjmując w tym tekście zasadę współczynnika humanistycznego F. Znanieckiego (2009 [1934]: 67-68; 1931: 10-11), aby z całą mocą powiedzieć, że migracja jakiegoś człowieka jest już zakończona, trzeba nie tyle dowiedzieć się, jak długo przebywa on w nowym miejscu, ale pytać o to, czy czuje się on współwłaścicielem przestrzeni, w której mieszka. W tej perspektywie dopiero poczucie, warunkowane wieloma psychicznymi i społecznymi czynnikami, że jest się "tutejszym”, pozwala mówić o końcu migracji, czyli o - powróćmy do użytej wcześniej metafory - "zakorzenieniu” w danym miejscu, w przestrzeni na początku migracji jeszcze nieznanej, a teraz uważanej już za własną. Jak wcześniej wspomniano, tym, co będzie nas interesować w niniejszym tekście, jest właśnie doświadczanie przestrzennego i społecznego procesu migracji.

Pojęcie migrantów będzie odnoszone, przy zapożyczeniu terminów wprowadzonych przez Stanisława Ossowskiego (1984 [1967]: 17-18, 26-30), zarówno do tych osób, które zamieszkały na stałe w przestrzeni innej niż ich ojczyzna ideologiczna (niem. Vaterland, obszar państwa lub ojczyzna w definicji ideologii narodowej), jak i do tych, które pozostając na terytorium ojczyzny ideologicznej, przeniosły się $\mathrm{w}$ obszar innej ojczyzny prywatnej 
(niem. Heimat, "mała ojczyzna”, miejscowość, miasto lub region). Pierwszy przypadek dotyczy migracji do innego państwa narodowego, opisywanych przez antropologów, socjologów, geografów czy kulturoznawców w kontekście integracji i dezintegracji społecznej, budowania i zanikania więzi wspólnotowych, konstruowania tożsamości jednostkowej i zbiorowej, kontaktu międzykulturowego czy, zwłaszcza w ramach studiów postkolonialnych, politycznej, klasowej i kulturowej dominacji. Tradycja badań nad migracjami z kraju do kraju sięga opracowań szkoły chicagowskiej, od początku zainteresowanej wpływem migracji na rozwój i tożsamość miast. Drugi rodzaj migracji - z jednej ojczyzny prywatnej do drugiej w ramach tej samej ojczyzny ideologicznej - również od dawna budzi zainteresowanie nauk społecznych. Ich przykład stanowią między innymi związane dawniej $\mathrm{z}$ industrializacją, a dziś z metropolizacją, migracje ze wsi i małych miast do dużych ośrodków, migracje w niekiedy złudnej „ucieczce” przed miejskością z centrum miast na ich obrzeża i obszary podmiejskie czy przemieszczanie się z jednego miasta do drugiego o odmiennej architekturze, gwarze, zwyczajach lub autostereotypach. W kontekst ten należy wpisać badania szkoły neoekologicznej nad stylami życia i charakterem miejskości w ogóle (m.in. prace Louisa Wirtha, Amosa H. Hawleya i ich kontynuatorów), poświęcone lokalnym społecznościom i kulturom, a także antagonizmom między mieszkańcami poszczególnych miast i dzielnic. Są to publikacje zarówno dotyczące współcześnie doświadczanej w Polsce suburbanizacji (m.in. prace Katarzyny Kajdanek), jak i poruszające tematykę osadnictwa na Ziemiach Zachodnich po II wojnie światowej, również odbywającego się w granicach - choć wówczas całkiem „świeżych” - jednej ojczyzny ideologicznej (Kwaśniewski 1987; zob. także liczne z tego zakresu raporty z badań Zygmunta Dulczewskiego, Andrzeja Kwileckiego czy Władysława Markiewicza).

Choć przeprowadzka poza obszar ojczyzny ideologicznej wiąże się z większymi zmianami społecznymi w życiu migranta niż zamieszkanie jedynie $z$ dala od ojczyzny prywatnej, to zarówno migracje pierwszego, jak i drugiego rodzaju wiążą się niechybnie i naturalnie $\mathrm{z}$ narażeniem na doświadczenie obcości, która pojawia się, jak pisał F. Znaniecki (1931: 22), w każdej sytuacji, w której stykają się odmienne układy wartości. Migracje, i do innej ojczyzny ideologicznej, i do innej ojczyzny prywatnej, wiążą się z kontaktem z ludźmi o odmiennych zwyczajach, kulturze (w sensie wąskim lub szerokim), języku, gwarze czy dialekcie, sposobach nawiązywania kontaktów i ich podtrzymywania, definiowania i przeżywania wspólnoty itd.

Migrant, co ciekawe, doświadczać może obcości zarówno przebywając w społeczności przyjmującej, jak i w czasie powrotów do społeczności wysy- 
łającej - za każdym razem bowiem można go zdefiniować jako kogoś, kto właśnie przybył „stamtąd” do nas, czyli „tutaj”, i zamieszkał (po raz pierwszy albo ponownie, na chwilę) $\mathrm{w}$ naszej przestrzeni. Spotkanie $\mathrm{z}$ migrantem stawia więc przed zbiorowością mieszkańców jakiegoś terytorium pytanie o to, czy jest to jedynie Przybysz (Gość lub Przybłęda - jeśli posłużylibyśmy się ponownie terminami zaproponowanymi przez F. Znanieckiego (1938: 106-108)), czy też Współwłaściciel tej przestrzeni. Dla samych migrantów ich własna migracja wymaga z kolei ciągłego definiowania, jakie miejsca denotować będą dla nich przysłówki „tam” i „tutaj”. O ile bowiem dla pozostających $\mathrm{z}$ reguły $\mathrm{w}$ jednej geograficznie określonej przestrzeni wspólnot terytorialnych (większych, jak np. naród, lub mniejszych, jak np. mieszkańcy jakiegoś miasta) "tutaj” jest bardzo dobrze określone, to dla migrantów jest to często kwestia problematyczna, a ich odpowiedzi na pytanie "skąd jestem?" ukazują często złożoność ich tożsamości, jeśli nie konfliktowość różnych jej elementów.

\section{PRZYGODA I WYGNANIE - DWA MODELE PRZEŻYWANIA WŁASNEJ MIGRACJI}

Stosunek migranta do własnej migracji i doświadczanej obcości może być dwojaki. W pierwszej perspektywie migracja - owo specyficzne, jedynie migrantowi znane napięcie między "tu" i "tam" - nazywana jest Przygodą, w drugiej zaś Wygnaniem. Oczywiście, zarówno Przygoda, jak i Wygnanie odnoszą się do modelowych sytuacji, Weberowskich typów idealnych, pomiędzy którymi znajduje się niezliczona liczba stanów pośrednich.

Współczesna socjologia widzi w Filozofii przygody Simmla (2006 [1910]) esej o jednym z możliwych sposobów przeżywania własnej migracji. W tym ujęciu migracja doświadczana jest jako Przygoda, gdy stanowi dla migranta wyjątkowy, jednak mający swój początek i koniec odcinek życia. Jak pisze Simmel (2006 [1910]: 257),

\footnotetext{
„Przygoda stanowi, rzecz jasna, cząstkę naszej egzystencji, dołącza bezpośrednio do tego, co ją poprzedza i co po niej następuje, lecz zarazem w głębszym sensie znajduje się poza ciągłością życia. A przecież różni się od wszystkiego, co po prostu przypadkowe, obce, muskające tylko naskórek życia. Wypada z całości życia, ale [...] niejako tym samym ruchem wraca do niego, jest obcym ciałem w naszej egzystencji, choć zarazem jakoś powiązanym z jej centrum".
}

Dodajmy, że migracja może być przeżywana jako Przygoda, nawet jeśli przeświadczenie migranta o tymczasowości pobytu "tam” jest nieuzasad- 
nione i fałszywe. Przypomnijmy choćby tych migrantów, którzy przeżyli większość, jeśli nie całe swoje życie, w przekonaniu o przygodności swej migracji, karmieni tzw. „iluzją powrotu”, objawiającą się w ciągłym odkładaniu powrotu do kraju pochodzenia. Tymczasem, jak słusznie pisze Simmel (2006 [1910]: 257), cechą każdej Przygody jest to, że choć ma swój początek i koniec, to jednocześnie "sama zakreśla swe granice", trudno przewidzieć jej zakończenie.

Drugą, już zasygnalizowaną w cytowanym wyżej fragmencie, właściwością Przygody jest jej sens, czyli powiązanie „z istotą i powołaniem podmiotu", co odróżnia ją od zdarzeń wynikających ze zwykłego przypadku (Simmel 2006 [1910]: 258). Choć niemiecki filozof i socjolog nie pisze tego wprost, jasne jest, że osobie doświadczającej Przygody towarzyszą zarówno ułatwienia, jak i trudności w realizacji jej sensu. Pozostaje jednak ważne, iż niezależnie od tego, czy migracja (lub pewne jej etapy) jest w oczach migranta dobrą czy złą Przygodą, to dostrzega on jej związek z urzeczywistnianiem się jakiegoś szerszego niż migracja osobistego planu, a często jej powiązanie z życiowymi marzeniami i ambicjami. Dlatego tym, co cechuje osobę realizującą cel Przygody, jest, jak pisze Simmel (2006 [1910]: 261-264), postawa zdobywcy i śpieszne chwytanie szansy, śmiałość w działaniu, stawianie wszystkiego na jedną kartę i na los szczęścia, wiara w powodzenie planu i pewność, której nie są w stanie zmącić nawet przemawiające przeciw niej fakty. „W naszym życiu działanie splata się z doznawaniem, w przygodzie oba te elementy ulegają jednocześnie spotęgowaniu: postawa zdobywcy, który wszystko zawdzięcza własnej sile i przytomności umysłu, oraz całkowite zdanie się na żywioły i szanse świata, które mogą nas uszczęśliwić, ale także zniszczyć" (Simmel 2006 [1910]: 261-262).

O ile w doświadczaniu Przygody następuje, zdaniem Simmla (2006 [1910]: 261), synteza bierności i aktywności, o tyle doświadczenie Wygnania nie sprzyja postawie zdobywcy. Badaczem społecznym, który zwrócił uwagę na ten aspekt migracji, był socjolog Abdelmalek Sayad zajmujący się migracjami Algierczyków do Francji. Sayad (1999) przekonywał, że określenie "imigrant" odnosi się nie do statusu prawnego, ale przede wszystkim do kondycji społecznej. Ta zaś ściśle wiąże się z przekonaniem migranta o tym, że zarówno $\mathrm{w}$ miejscu emigracji, jak i imigracji, nie jest do końca u siebie. Doświadczenie Wygnania polega na odkryciu przez migranta jego "podwójnej nieobecności":

„Tym jest emigracja, to przeżywanie obcości w jakimś kraju. [...] Nasza elghorba, wygnanie, to przyjeżdżanie za każdym razem w spóźnieniu: przyjeżdżasz tutaj i nic nie wiesz, musisz wszystko odkrywać, wszystkiego się uczyć, wszystko nadrabiać, jesteś 
zawsze spóźniony w stosunku do innych emigrantów i do Francuzów, zawsze o jeden krok w tyle. A potem, kiedy wracasz do swojej wioski w Algierii, zdajesz sobie sprawę, że nie masz nic, że straciłeś gdzieś swój czas" (Sayad 1999: 95).

W przeciwieństwie do doświadczenia Przygody Wygnanie jawi się jako sytuacja bez dobrego i pewnego zakończenia. Choć pobyt "tam” doznawany jest przez migranta jako bardzo uciążliwy, to nie decyduje się on na przerwanie migracji, pamiętając o powodach, dla których zdecydował się emigrować. Powiedzielibyśmy (przez analogię do Simmlowskiej propozycji, ale także na podstawie tego, co pisał Sayad w La double absence. Des illusions de l'émigré aux souffrances de l'immigrê), że migrant-Wygnaniec nie ma już tej pewności, choćby nawet była ona ślepa i bez pokrycia, dotyczącej szczęśliwości losu i pojawienia się okoliczności sprzyjających realizacji migracyjnego planu. Wygnańcowi brak wiary we własne siły, nie przyjmuje więc postawy zdobywcy, ale czuje się przegrany. Kolejną różnicą jest wrażenie ciągłego spóźnienia, bycia o jeden krok zarówno za tymi, którzy są "tam”, jak i tymi "tutaj”. Tymczasem, przeżywając Przygodę, migrant czuje, że uczestniczy w grze, że jest aktywnym aktorem wydarzeń.

Wygnaniec nie widzi nadrzędnego sensu swej migracji dla całości swego życia, który tak mocno charakteryzował Przygodę. Ilustracją doświadczenia Wygnania jest cytowana przez Sayada wypowiedź jednego z pracowników algierskich we Francji z 1975 r.: "Jaką Francję odkryłem! To zupełnie nie było to, czego się spodziewałem [...]. I to ja, który wierzyłem, że Francja nie będzie dla mnie wygnaniem. Dopiero kiedy przyjedzie się tu, poznaje się prawdę. Dopiero tutaj [we Francji - dop. J.K.] słyszy się rzeczy, których nigdy nie mówi się tam, u nas w kraju; wszędzie tutaj słyszy się: «to nie jest życie dla ludzi» [...]" (Sayad 1999: 38). Tym, co najbardziej uderza w cytowanej wypowiedzi, jest rozpacz imigranta wywołana na wspomnienie pierwszego widoku innych Algierczyków śpiących po kilku w małych pokojach: "Jakiż smutek! Jakież nieszczęście w ich spojrzeniach, w ich głosie i w tym, co mówili ściszonym głosem. W tym momencie ujrzałem, czym jest samotność i czym jest smutek: w ciemności tego pokoju [...], w ciemności ulicy... w ciemności całej Francji, ponieważ, w tej naszej Francji, takiej, jaka była nam dana, nie było nic oprócz cieni" (Sayad 1999: 38).

Mówiąc o Wygnaniu, podkreślmy, że doświadczać go będzie osoba tęskniąca za ojczyzną prywatną bądź ideologiczną, traktująca swą migrację nie do końca jako własny, wolny wybór, ale jako wynik mniej lub bardziej wyraźnych nacisków rodziny, lokalnej społeczności czy sytuacji politycznej. Wygnańcem będzie więc ktoś, kto znalazł się w nowym miejscu, chociaż całkowicie lub z pewnych tylko powodów - wolałby żyć gdzie indziej. 
Wygnańcem jest zatem cytowany wyżej Algierczyk, który czuje się we Francji smutny i upokorzony, ale jest nim również każdy, kto zyskał w tym kraju szansę rozwoju artystycznego, naukowego czy azyl polityczny i czuje się w tym kraju szczęśliwy, choć jednocześnie pozostawił jakąś ważną cząstkę swego "Ja" tam, skąd pochodzi, gdzie nie mógł realizować wszystkich swych marzeń. Wygnanie, podobnie jak pojęcie Przygody, odnosi się więc do migracji, metaforycznie ujętej jako zapuszczanie korzeni w jednym miejscu i ucinania ich $\mathrm{w}$ innym, do procesu przestrzennych i społecznych przenosin, nie zaś do oceny określonej przestrzeni, w której migrant przebywa obecnie lub przebywał niegdyś.

Przygoda i Wygnanie określają stany i doświadczenia, co do których migranci żywią przekonanie, że nie przeżywaliby ich, gdyby nie wyruszyli swym migracyjnym szlakiem. Dla jednych alternatywą dla migracji-Przygody jest zwyczajny, znany i oswojony nurt życia, drudzy z kolei wybierają między migracją-Wygnaniem a pozostaniem $\mathrm{u}$ siebie i rezygnacją $\mathrm{z}$ dowiedzenia się, jak wyglądałoby ich życie "tam”.

Kresem zarówno Przygody, jak i Wygnania jest kres samej migracji, który - jak stwierdziliśmy wcześniej - dokonuje się przede wszystkim w świadomości samego migranta. Gdy migrant czuje się "na nowym” jak u siebie, kiedy nie chciałby już w żadnej mierze wrócić do wcześniejszego miejsca pobytu (wtedy "na nowym” nie jest już Wygnańcem) i kiedy z miejscem przyjazdu wiąże całe swoje życie (gdy nie przeżywa już Przygody), kończy się dla niego migracja. Jak wiemy, dzieje się tak stosunkowo rzadko w przypadku pierwszego pokolenia migrantów; ich migrację dużo częściej kończą "za nich" ich dzieci, które ojczyznę prywatną i ideologiczną wiążą generalnie z jednym miejscem.

Powiedzmy jeszcze, że różnica między Przygodą i Wygnaniem nie polega na odmiennych przyczynach wyjazdu i warunkach życia w miejscu bądź kraju przyjazdu ani na odmiennych trajektoriach migracyjnych, ale na sposobie doświadczania tych wszystkich elementów składających się na migrację. Zaprezentowane tu - modelowe i na pewno nie jedyne możliwe - sposoby przeżywania własnej migracji nie wykluczają się wzajemnie. Ta sama migracja może być bowiem doświadczana raz jako Przygoda, innym razem jako Wygnanie, albo też jako Przygoda i Wygnanie jednocześnie.

\section{PRZYGODA I WYGNANIE - WYZWANIE POLITYKI MIEJSKIEJ}

Migranci, ludzie atopos, prawdopodobnie zawsze byli, jak długa jest historia municypalności, wyzwaniem dla polityki miejskiej. Dla miast, rozu- 
mianych jako wspólnoty mieszkańców o różnych statusach i proweniencjach, wyzwaniem jest zapewnienie - pomimo obiektywnych różnic - samego faktu istnienia tej wspólnoty, której członkowie współdzielą pewne wartości, w tym - jak pisał F. Znaniecki - wartości przestrzenne. Jakkolwiek różne są doświadczenia Wygnania i Przygody, to jednak każde z nich sprawia, że imigrant nie czuje się ani integralną, stałą częścią miejskiej wspólnoty, ani współwłaścicielem dzielonych przez nią wartości. Co zatem mogą czynić zarządy miast lub poszczególnych dzielnic, aby migrant życia w nich nie traktował ani jako Przygody, ani jako Wygnania?

Zanim odpowiemy na to pytanie, zastanówmy się jeszcze nad innym: Czy w ogóle stworzenie tak rozumianej wspólnoty miejskiej jest możliwe? Łatwiej przecież mówić o mieście jako konglomeracie grup i zbiorowości niż jako jednym, współdzielącym jakieś konkretne wartości, społeczeństwie. Ponadto, jak wiemy, cechą nowoczesnych i ponowoczesnych miast jest właśnie brak wzajemnej więzi między mieszkańcami (zob. Simmel 2005 [1903]: 305-315), a poczucie, że jest się obcym w "samotnym tłumie” (zob. Riesman 2011 [1950]), towarzyszy wielu ludziom w mieście, nie tylko migrantom. Jak pisał A. Wallis (1967: 132), "[...] przynależność do tej samej zbiorowości wielkomiejskiej nie pociąga za sobą na co dzień solidarności mieszkańców. [...] Płaszczyzny solidarności wyznaczają wartości inne - zawodowe, kulturalne, religijne. [...] Obcość dwóch mieszkańców tego samego domu lub bloku może być nie mniejsza niż mieszkańców dwóch różnych miast, którzy się nie znają i nic o sobie nie wiedzą".

Z drugiej strony współcześnie dostrzega się, że miastom potrzeba polityki, która stwarzałaby dogodne warunki do doświadczania wspólnoty przez mieszkańców, w tym przez imigrantów. Cel - doświadczenie wspólnoty $\mathrm{w}$ mieście - jaki stawiałaby przed sobą polityka miejska, wydaje się dość utopijny, jednak, jak przekonuje wielu autorów (zob. Vermeulen, van den Akker 2010), obecnie potrzebujemy właśnie tego rodzaju utopijnych propozycji, chociażby brzmiały one dla nas mało prawdopodobnie. $\mathrm{W}$ istocie, utopią jest program zakładający odbudowę poczucia wspólnoty po postmodernizmie, który nauczył nas obawiać się wielkich narracji i wiary w silne, zbiorowe podmioty. Nie chodzi tu jednak o powrót do wielkich modernistycznych idei ani do - często z nimi wiązanych - totalitarnych utopii społecznych. Nie, nowa polityka miejska odrzuca postmodernistyczną ironię i strach przed autentycznym przywiązaniem do zbiorowych tożsamości, a jednocześnie owe płaszczyzny doświadczania kolektywnego "my" chce budować na zupełnie innych niż modernistyczne fundamentach. Jak piszą Lech Mergler, Kacper Pobłocki i Maciej Wudarski (2013: 37-38), w interesie mieszkańców nie znajduje się polityka miejska, która opierając się na 
takich pojęciach, jak „lewica” i „prawica” (a także, dodajmy, „naród”, ,etniczność", „rasa” czy „klasa”), i odwołując się do abstrakcyjnych, symbolicznych idei, nie tylko nie pomaga w budowaniu pozytywnych społecznych relacji w mieście, ale wręcz wywołuje podziały między mieszkańcami. Tym, czego potrzeba miastu, jest polityka stwarzająca możliwość budowania wspólnoty (wbrew wątpiącym w jej sens postmodernistom) wokół konkretnych problemów i projektów, nie zaś wokół ogólnonarodowych czy ogólnoklasowych haseł (jak pewnie widzieliby to moderniści). W takich wspólnotach, choć doświadczanych chwilowo i w ograniczonym zakresie - wtedy, kiedy pojawia się jakaś konkretna potrzeba - znajduje się miejsce na różnorodność ideową, narodową, klasową, jest również miejsce dla imigrantów mieszkających w mieście bez względu na to, czy mają oni obywatelstwo danego państwa czy też nie. „Odniesienie się do miasta, do przestrzeni oraz do tego, co nazywamy narracją konkretną, sprawia, że ludzie, traktowani jako obywatele lub mieszkańcy określonego obszaru, zaczynają rozumieć, że mają więcej wspólnego niż tego, co ich różni" (Mergler, Pobłocki, Wudarski 2013: 38).

Proponowana tutaj polityka miejska opiera się na wspólnotach tymczasowych, zogniskowanych wokół ważnych dla wszystkich mieszkańców spraw, podzielających wspólne, $w$ terminologii F. Znanieckiego, wartości przestrzenne i mających wszelkie prawo, aby czuć się ich właścicielami. Współcześnie o zasadności polityki budującej właśnie takie wspólnoty polityki, która ciągle wydaje się niezrealizowaną utopią - przekonują ruchy miejskie łączące mieszkańców wokół konkretnych problemów, a jednocześnie połączone siecią kontaktów z działaczami podobnych ruchów w innych państwach (Swyngedouw, Kaika 2005: 174-175). Co ważne, „ruchy miejskie nie skupiają rewolucjonistów, których celem jest obalenie systemu polityczno-społecznego, ale mniej lub bardziej radykalnych reformatorów systemu. Owa reforma nie jest wymyślona czy zaplanowana «odgórnie», lecz wychodzi od konkretów, w których naocznie stwierdzamy dysfunkcjonalność systemu lub jego fragmentów" (Mergler, Pobłocki, Wudarski 2013: 38). Jeśli chodzi o działania skierowane na rozwiązywanie konkretnych spraw w miastach z dużym odsetkiem migrantów, to zaobserwować je można dziś zwłaszcza w krajach wielokulturowych. Przykładowo, w ramach programu Good Ideas in Integration prowadzonego przez kanadyjską fundację Maytree $\mathrm{w}$ wielu miastach na świecie udało się wprowadzić elementy postulowanej tu inkluzywnej polityki zapraszającej każdego mieszkańca, zwłaszcza tych - z różnych powodów - wykluczonych, do wspólnoty miejskiej. Inspirujące raporty $z$ tego rodzaju działań odnaleźć można na stronie interneto- 
wej poświęconej „Miastom migracyjnym” („Cities of Migration. A Maytree Idea", http:/ / citiesofmigration.ca/).

Rola imigrantów, czyli ludzi łączących różne światy społeczne i mających doświadczenie życia zarówno "tam”, jak i „tu”, w budowaniu polityki miejskiej opierającej się na tymczasowych wspólnotach jest trudna do przecenienia. $Z$ drugiej strony otwarcie polityki miejskiej na imigrantów, traktowanie ich w taki sam sposób jak innych mieszkańców, może znacząco przyśpieszyć proces ich społecznego zakorzeniania się $\mathrm{w}$ nowym miejscu i w praktyce - zakończenia ich własnej migracji, niezależnie od tego, czy była ona dla nich Przygodą czy też Wygnaniem. Umożliwienie migrantom, podobnie jak innym mieszkańcom, udziału w wyborach miejskich, podejmowania decyzji dotyczących miasta i aktywnego angażowania się w zabiegi na rzecz poprawy jakości życia w nim ocenić więc należy jako działania pozytywne i pożądane, choć ciągle trudne do realizacji.

\section{BIBLIOGRAFIA}

Bourdieu P. (1999), Préface, [w:] A. Sayad, La double absence. Des illusions de l'émigré aux souffrances de l'immigré, Seuil (Liber), Paris.

Cities of Migration. A Maytree Idea, http:/ / citiesofmigration.ca/ [dostęp: 20.10.2013].

Kwaśniewski K. (1987), Autochtonizm i autochtonizacja, „Ruch Prawniczy, Ekonomiczny i Socjologiczny" 1987, nr 1.

Mergler L., Pobłocki K., Wudarski M. (2013), Anty-Bezradnik przestrzenny: prawo do miasta $w$ działaniu, Fundacja Res Publica im. H. Krzeczkowskiego, Warszawa.

Ossowski S. (1984 [1967]), O ojczyźnie i narodzie, PWN, Warszawa.

Riesman D. (2011 [1950]), Samotny tłum, Wydawnictwo Vis-à-vis/Etiuda, Kraków.

Sayad A. (1999), La double absence. Des illusions de l'émigré aux souffrances de l'immigré, Seuil (Liber), Paris.

Simmel G. (2005 [1903]), Mentalność mieszkańców wielkich miast, [w:] idem, Socjologia, Wydawnictwo Naukowe PWN (Biblioteka Socjologiczna), Warszawa.

Simmel G. (2006 [1910]), Filozofia przygody, [w:] idem, Most i drzwi. Wybór esejów, Oficyna Naukowa, Warszawa.

Simmel G. (2008 [1903]), Socjologia przestrzeni, [w:] idem, Pisma socjologiczne, Oficyna Naukowa (Biblioteka Myśli Socjologicznej), Warszawa.

Swyngedouw E., Kaika M. (2005), La production de modernités urbaines "glocales": explorant les failles dans le miroir, "Géographie, Économie, Société” 2005, no 2.

Vermeulen T., van den Akker R. (2010), Notes on Metamodernism, "Journal of Aesthetics \& Culture" 2010, no. 2.

Wallis A. (1967), Socjologia wielkiego miasta, PWN (Współczesna Biblioteka Naukowa Omega), Warszawa.

Wallis A. (1977), Miasto i przestrzeń, PWN, Warszawa. 
Znaniecki F. (1931), Studia nad antagonizmem do obcych, odbitka z „Przeglądu Socjologicznego" 1930-1931, nr 2-4, Rolnicza Drukarnia i Księg. Nakł., Poznań.

Znaniecki F. (1938), Socjologiczne podstawy ekologii ludzkiej, „Ruch Prawniczy, Ekonomiczny i Socjologiczny" 1938, nr 1.

Znaniecki F. (2009 [1934]), Metoda socjologii, Wydawnictwo Naukowe PWN (Biblioteka Socjologiczna), Warszawa. 